\title{
An integrated model for the magmatic evolution of alkaline melts from Oldoinyo Lengai
}

\author{
CÉLINE BAUDOUIN ${ }^{1,2}$, LYDÉRIC FRANCE ${ }^{3}$, GAËLLE \\ MOLLEX $^{2}$ AND GUILLAUME BOUDOIRE ${ }^{4}$ \\ ${ }^{1}$ Université Le Mans \\ ${ }^{2} \mathrm{CRPG}, \mathrm{CNRS}$ \\ ${ }^{3}$ Université de Lorraine, CNRS, CRPG \\ ${ }^{4}$ Laboratoire Magmas et Volcans \\ Presenting Author: celine.baudouin@univ-lemans.fr
}

Oldoinyo Lengai is the only active carbonatite-phonolite volcano on Earth. The various available igneous products allow us to quantify the key magmatic processes that govern its differentiation series, and the relationships between silicate melt and carbonatite. In the last decades, Oldoinyo Lengai has been extensively studied through petrography, geochemistry and experiments leading to several petrogenetic and eruptive models. Here, we present a review of literature data, together with new chemical data from cognate cumulate samples that probe the active magma reservoir during the 2007-2008 explosive eruption. New data include the composition of melt inclusion hosted in clinopyroxene, garnet, and nepheline, and of interstitial melt that together are used to track the ongoing magmatic processes during this last explosive eruption. Melt inclusions have similar compositions to that observed for the 1917, 1966 and 1993 explosive eruptions, and allow the elaboration of a general model.

We describe 3 chemical components ( 2 chemical trends) based on major elements that can be used to constrain magmatic processes during the differentiation. The dominant stage of the eruptive cycle is steady state and operates at open conduit conditions with the effusion of carbonatite magmas at surface from a likely stratified shallow reservoir (stagnant carbonatite on silicate magma; component A). Destabilisation of the system triggering the explosive eruption is likely related to the recharge of a Na-, Ca-poor melt identified in some clinopyroxene-hosted melt inclusions (component $B$ ). Mixing between the resident and recharge silicate magmas can be tracked within the melt inclusion series. During the explosive stage, melt continues to differentiate at depth (B to C component composition) through protracted crystallisation of nepheline, wollastonite, apatite and minor clinopyroxene and garnet minerals.

We eventually propose an integrated model using the previous extensive studies and the new data acquire herein to constrain the temporal evolution of magmas, and the related differentiation processes within mid-crustal reservoirs of the Oldoinyo Lengai plumbing system. 